Annals of Tropical Research 31[1]:34-46(2009)

(c) VSU, Leyte, Philippines

\title{
Carbohydrate status of sucrose-fed broccoli head during storage and the activity and gene expression of sucrose synthase
}

\author{
Dewoowoogen P. Baclayon ${ }^{1}$ and Toshiyuki Matsui ${ }^{2}$ \\ ${ }^{1}$ Plant Tissue Culture and Disease Diagnostic Laboratory Research, \\ Development and Extension Office, Southern Leyte State University-Main Campus \\ Sogod, Southern Leyte, Philippines \\ ${ }^{2}$ Department of Applied Biological Sciences, Faculty of Agriculture, \\ Kagawa University, Miki-cho, Kagawa-ken, Japan
}

\begin{abstract}
Quality deterioration in broccoli is associated with rapid loss of sucrose after harvest. Hence, this study was conducted to investigate the influence of exogenous application of $10 \%(\mathrm{w} / \mathrm{v})$ sucrose to broccoli heads during storage at $20^{\circ} \mathrm{C}$ on the activity and gene expression of sucrose synthase. The level of sucrose in the branchlets and florets tissues was improved only within a day and 2 days, respectively, from treatment. The enzyme activity in both portions was inconsistent with SS gene expression thereafter. The decline in sucrose could be a consequence of concerted actions of other harvest related genes in addition to SS. It is possible that SS could be encoded by multi-genes as exhibited in other plant species. Further characterization or isolation of different SS isoforms and their expressions during postharvest senescence would be helpful in the regulation of sugar metabolism in harvested heads during storage.
\end{abstract}

Keywords: BoSS, enzyme, fructose, glucose, postharvest life, senescence, sugar

Correspondence: D. P. Baclayon Address: Plant Tissue Culture and Disease Diagnostic Laboratory Research, Development and Extension Office, Southern Leyte State University-Main Campus Sogod, Southern Leyte, Philippines. E-mail:dpbaclayon@yahoo.com. Tel/Fax No. 63-53-3823264

DOI: $10.32945 /$ atr3112.2009 


\section{INTRODUCTION}

Broccoli (Brassica oleracea L.) is a plant of the Brassicaceae produced in cool-weather countries worldwide for its nutritional and therapeutic importance to the human health. Broccoli benefits health beyond providing just basic nutrition, hence consumption has been increasing through the years. However, the high perishability of the commodity is a major constraint in postharvest handling and marketing.

Quality deterioration in harvested broccoli is manifested by rapid decline in appearance accompanied by loss in flavor and nutrient value. It has been reported that major physio-biochemical changes occurred after the head is severed from the mother plant. For instance, ammonia accumulates (Baclayon et al., 2006) while sugar contents drop rapidly (Pramanik et al., 2005) after harvest. These biochemical changes occurred due to changes in the activities of their metabolizing enzymes.

Specifically, changes in sugar levels have been reported to have severe effects on the shelf life of green vegetables including broccoli, lettuce and Chinese cabbage (Buchanan-Wollaston et al., 2003). In sugar metabolism, sucrose is the main form of sugar transported to the sink tissues (Nishikawa et al., 2005; Rosa et al., 2001). Sucrose is degraded via two alternative pathways, namely; hydrolysis by invertase and cleavage by sucrose synthase (sucrose-uridine-diphosphate-glucosyltransferase; SS; EC 2.4.1.13). SS catalyzes the reversible conversion of sucrose in the presence of uridine-diphosphate into uridine-diphospo-glucose and fructose.

Two or three genes encoding SS isoforms have been isolated from different plant species (Martinez de Ilarduya et al., 1993; Huang et al., 1996; Martin et al., 1993; Fu and Park, 1995) with contrasting sequence features and/or expression patterns. The expression of SS gene are cellspecific, developmentally regulated or regulated by tissue carbohydrate status (Koch et al., 1992; Ruan et al., 1997) and have also been significantly modulated in response to changing sugar supply (Stitt and Sonnewald, 1995; Koch, 1996).

Postharvest sugar application has been reported to increase the longevity of some important horticultural commodities such as roses (Ichimura et al., 1999), carnation (Verlinden and Garcia, 2004) and 
broccoli (Nishikawa et al., 2005; Irving and Joyce, 1995). It could be pointed out that the essential roles of sugars as sources of carbon skeleton for the complex biochemical metabolism in plants contribute to the postharvest life of perishable commodities. It was further reported that exogenous sucrose application in broccoli can improve postharvest quality by altering ethylene metabolisms (Nishikawa et al., 2005), keeping higher level of chlorophyll in the florets (Coupe et al., 2003), and increasing ascorbic acid levels (Smirnoff and Pallanca, 1996).

This study investigated the influence of exogenous sucrose-feeding on the activity and gene expression patterns of sucrose synthase in broccoli during storage. Findings would provide insights either in regulating biochemical reactions by molecular manipulations or designing suitable postharvest management practices that would extend the shelf life of broccoli.

\section{MATERIALS AND METHODS}

\section{Plant material and treatment}

Fresh broccoli cv. 'Pixcels' heads harvested from Kagawa Agricultural Experiment Station, Miki, Kagawa, Japan were trimmed and brought to the laboratory for treatment. One set consisting of 36 heads were immersed in freshly prepared $10 \%(\mathrm{w} / \mathrm{v})$ sucrose solution with $0.05 \%(\mathrm{v} / \mathrm{v})$ sodium hypochlorite $(\mathrm{NaClO})$ and replaced every $24 \mathrm{~h}$. The other set was immersed in distilled water as control. The heads were placed in perforated plastic sheet and incubated at $20^{\circ} \mathrm{C}$ for up to five days. Three samples were taken from each set daily and partitioned into florets and branchlets, treated with liquid nitrogen and kept at -30 and $80^{\circ} \mathrm{C}$ for storage until needed for enzyme assay and RNA extraction, respectively. 


\section{Soluble sugars determination by HPLC}

Total sugar was extracted by homogenizing approximately 4-g of sample tissue with $0.5 \mathrm{~g}$ sea sand and $10 \mathrm{ml}$ of distilled water in a cooled mortar and pestle. The extract was centrifuged at $11,000 \mathrm{x} \mathrm{g}$ for $10 \mathrm{~min}$ and the supernatant was filtered through a cellulose nitrate membrane filter ( 0.5 um pore size, Toyo, Japan). Soluble sugars were analyzed by high performance liquid chromatography (HPLC) with a silica gel-packed (C 610) stainless steel column (10.7 mm ID x $30 \mathrm{~cm}$ ) and D-2500 chromato-Integrator (Hitachi, Japan). The filtered air-free water was pumped through the column at a flow rate of $1 \mathrm{ml} \mathrm{min}^{-1}$. The pressure was adjusted to $24-25 \mathrm{~kg}-\mathrm{cm}^{-2}$ and the column temperature to $60^{\circ} \mathrm{C}$. Sucrose, glucose and fructose were identified by their retention times and were quantified according to standards.

\section{Sucrose synthase extraction and assay}

Approximately five grams from each portion of the broccoli head was added with $1 \%$ polyvinyl pyrrolidone (PVP), $1 \mathrm{~g}$ sea sand and $10 \mathrm{ml}$ of $0.2 \mathrm{M}$ potassium phosphate (K-P) buffer solution ( $\mathrm{pH} 7.8$ ) containing $10 \mathrm{mM}$ ascorbate, $15 \mathrm{mM} \mathrm{MgCl}_{2}, 1 \mathrm{mM}$ EDTA and $1 \mathrm{M}$ DTT. The samples were homogenized using a cooled mortar and pestle (previously kept at $-80^{\circ} \mathrm{C}$ ). The homogenate was squeezed through four layers of cotton cloth and the filtrate was centrifuged at $11,000 \times \mathrm{g}$ for $20 \mathrm{~min}$. The supernatant was dialyzed using a membrane (size 36, Wako, Japan) with 40 times diluted extraction buffer (0.2 M K-P; $\mathrm{pH} 7.8)$ for $16 \mathrm{~h}$. The solution that remained inside the membrane was used as the crude enzyme. The extraction procedure was carried out at $0-4^{\circ} \mathrm{C}$.

Enzyme activity was assayed following the method described by Hubbard et al. (1989) with slight modifications. Briefly, a total of 70.75 $\mu \mathrm{l}$ reaction mixture containing $50 \mathrm{mM}$ Hepes-NaOH buffer $(\mathrm{pH} 7.5), 15$ $\mathrm{mM} \mathrm{MgCl}{ }_{2}, 25 \mathrm{mM}$ fructose, and $25 \mathrm{mM}$ UDP-glucose was used. The mixture was incubated for $30 \mathrm{~min}$ at $37^{\circ} \mathrm{C}$ and the reaction was terminated with the addition of $70 \mu \mathrm{l}$ of $30 \% \mathrm{KOH}$. The test tubes were kept at $100^{\circ} \mathrm{C}$ for $10 \mathrm{~min}$ to destroy the remaining fructose. After cooling, $2 \mathrm{ml}$ of anthrone reagent (150 mg anthrone per $100 \mathrm{ml}$ of $70 \% \mathrm{H}_{2} \mathrm{SO}_{4}$ ) was added and incubated in $40^{\circ} \mathrm{C}$ water bath for $15 \mathrm{~min}$. The assay mixture 
was cooled and color development was measured at $\mathrm{A}_{620} \mathrm{~nm}$ using a UVVIS spectrophotometer(UV-1200, Shimadzu, Japan). Protein content was determined using bovine serum albumin as standard following the method of Lowry et al. (1951). The enzyme activity was measured as $\mu$ mole of sucrose produced per min per milligram of protein.

RNA extraction and BoSS gene expression analysis

RNA extraction and Northern blot analysis were performed as described by Baclayon et al. (2006) and Pramanik et al. (2005).

\section{RESULTS}

\section{Soluble sugar contents}

Sucrose content in both tissues of sucrose-fed heads increased $24 \mathrm{~h}$ after treatment and the content was significantly higher than the control heads (Fig. 1). Glucose content continuously increased in the branchlets while a decrease was observed in the floret portion. Glucose content was higher in the sucrose-fed heads after day 1 from treatment. However, the level of this sugar in the floret of sucrose-fed heads was not significantly different with that of the control at the end of the storage period. Among the three sugars, fructose, on the average, constituted the highest proportion in both portions. The amount slightly increased in the branchlet portion with storage time. In the floret portion, fructose significantly declined after day 2 of storage in both treatments. Highest amount of sugars was found in the branchlet portion throughout the storage period except for sucrose on day 1 in the control branchlets.

\section{Sucrose synthase activity}

SS activity continuously increased until the end of the storage period in both tissues (Fig. 2). There was an abrupt transient increase in enzyme activity in the branchlets of sucrose-fed heads at day 1 of storage. The enzyme activity was significantly higher in branchlet than in the floret 

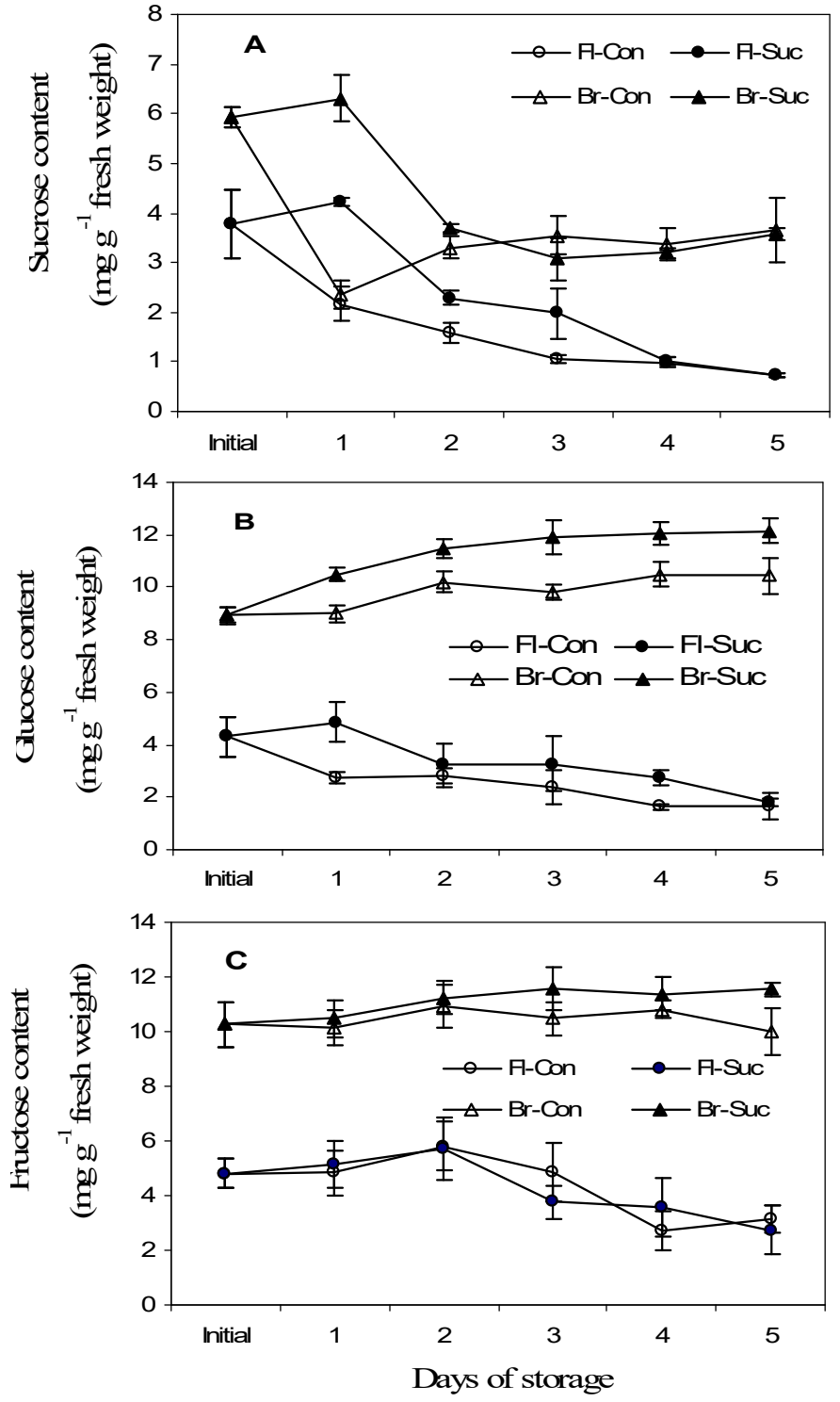

Figure 1. Changes in sugar contents (A: sucrose; B: glucose; C: fructose) in broccoli head supplied with exogenous sucrose during storage at room temperature. Legend: Fl-floret; Br-branchlet; Con-control; Suc-sucrose-fed. 


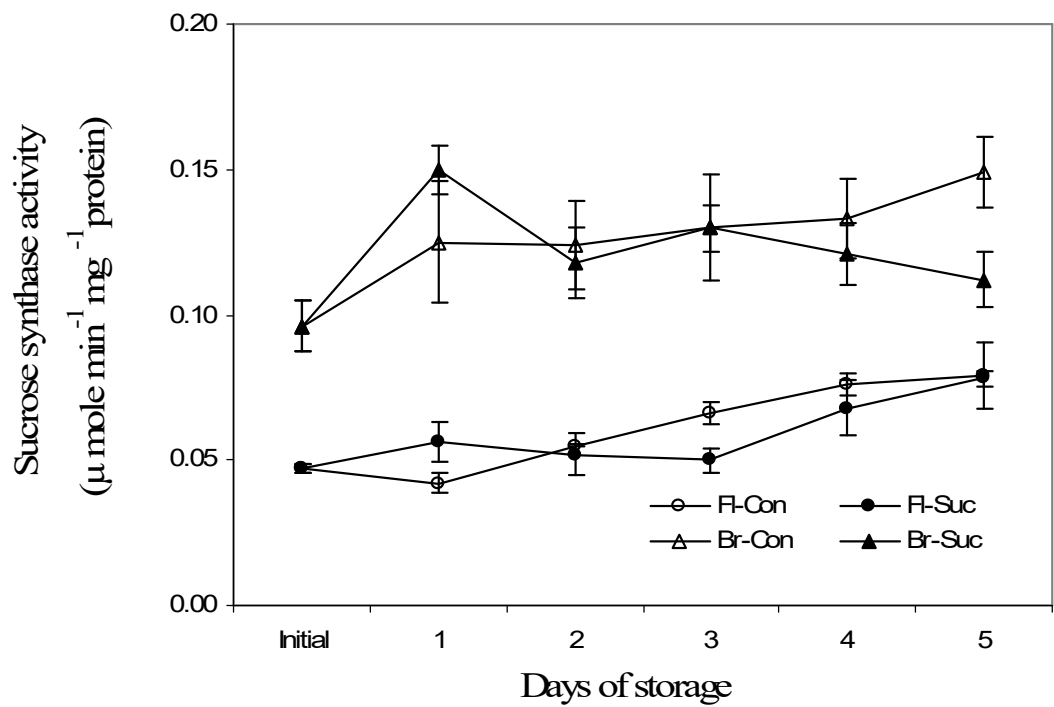

Figure 2. Changes in sucrose synthase activity in broccoli head supplied with exogenous sucrose during storage at room temperature.

Legend: as shown in Fig. 1. 
tissues regardless of treatment. It was further observed that SS activity of the control heads was lower during early period of storage than the treated heads. However, after day 2 of storage the enzyme activity in the sucrose-fed tissues was slightly higher than the control except on days 3 and 5 in the branchlets and floret tissues, respectively.

\section{BoSS gene expression}

To clarify the effect of sucrose-feeding on sugar metabolism at the molecular level, gene expression of BoSS was investigated by northern blot analysis using a Dig-labeled PCR probe with cloned cDNA from broccoli as template. SS transcripts in all tissues increased until day 2 of storage and remained at almost constant levels or slightly declined thereafter (Fig. 3). Highest intensity of transcript was observed in the branchlets of control heads.

\section{DISCUSSION}

Postharvest physiological change in harvested vegetables (Suthumchai et al., 2007; Sitthiwong, et al., 2007; Irving and Hurst, 1993) is characterized by rapid decline in sugars. Considering the important signaling functions of sugars throughout all stages of plants' life cycle and controlling gene expression (Smeekens, 2000), changes in their levels greatly affect tissue homeostasis. In this study, exogenous sucrose feeding generally improved sugar status of the tissues (Fig. 1). However, sucrosefeeding was not able to maintain the sucrose level as storage progressed. After day 1 of treatment, sucrose decline rapidly in both portions. It is possible that sucrose was cleaved into UDP-glucose and fructose by SS since the enzyme activity continuously increased throughout the storage period (Fig. 2). In lettuce, rapid decline in sucrose was correlated with increased SS activity (Suthumchai et al., 2007). Overall, sucrose degradation could be similar to that reported in vegetable soybean (Kassinee et al., 2004; Sitthiwong et al., 2007) in which both SS and acid invertase were singled out for sucrose breakdown. Hence, in this case, sucrose could also be hydrolyzed by acid invertase into its component 


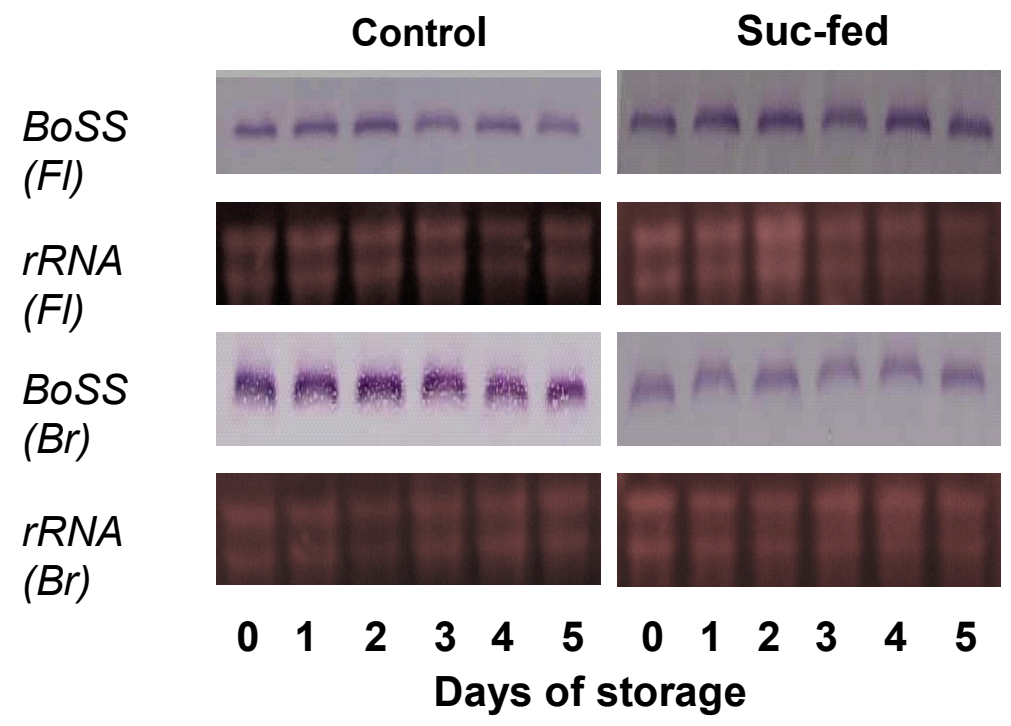

Figure 3. RNA gel blots of BoSS transcript in broccoli head supplied with exogenous sucrose during storage at room temperature. Equal loading of RNA was confirmed by staining a gel with ethidium bromide. 
monosaccharide, glucose and fructose as the levels of these sugars were increasing particularly in the branchlet tissues during storage. Furthermore, the concerted actions of other harvest related genes such as asparagine synthetase and ß-galactosidase (Davies et al., 1996) could have caused the significant decrease in sucrose content. The transient abrupt increase in sucrose level in sucrose-fed heads $24 \mathrm{~h}$ after harvest could be due to fresh cuts made on the base of the head which provided easy entry of sucrose solution. Thereafter, due to callus formation, sucrose uptake could be interfered. Further studies on the effect of fresh cut at the base of the head every after $24 \mathrm{~h}$ during storage is needed to give better understanding on the long term effect of sucrose feeding on the postharvest behavior of broccoli head.

Contrary to the glucose and fructose contents in the branchlets, the levels in the florets were decreasing. Except for a day delay in glucose decline in sucrose-fed tissues, the level continuously declined until the end of the storage period in both treatments. Fructose, on the other hand, started to decline 2 days after harvest and the patterns of changes were similar to that of the control tissues. The general decline in sugar contents in the florets could be attributed to high demand of sugars by the actively growing tissues in the florets. This organ is composed of immature and rapidly developing tissues hence, produced more $\mathrm{CO}_{2}$ than the branchlets (King and Morris, 1994). In addition to respiratory consumption, export from these tissues to the underlying stem (McKenzie et al., 2004) could also contribute to the major loss of sugars.

Northern blot analysis showed that BoSS gene expression was increasing until day 2 of storage and remained at almost same levels or slightly declined thereafter (Fig. 3). BoSS gene expression was only consistent with enzyme activity until day 2 of storage. This result may suggest that $\mathrm{SS}$ expression could be controlled by multigenes. In monocots such as maize (Koch et al., 1992), barley (Martinez de Ilarduya et al., 1993) and rice (Wang et al., 1992) and dicots such as Arabidopsis (Chopra et al., 1992; Martin et al., 1993), potato (Fu and Park, 1995) and tomato (Chengappa et al., 1998), two or more genes encoding SS isoforms have been isolated with contrasting sequence feature and/or expression patterns.

Based on the results, sucrose levels in the branchlets and florets can 
be improved only within 24 and $72 \mathrm{~h}$, respectively, from harvest with exogenous sucrose feeding. Results of RNA blot analysis suggest that SS gene expression is likely controlled by multigenes since the transcript was inconsistent with enzyme activity after two days from treatment. The decline in sucrose could be a consequence of concerted actions of other harvest related genes in addition to SS. Further characterization or isolation of different SS isoforms and their expressions during postharvest senescence would be helpful in the regulation of sugar metabolism in harvested heads during storage.

\section{ACKNOWLEDGMENT}

The authors are grateful for the financial support of the Government of Japan through the Ministry of Education, Culture, Science and Technology. They would also like to acknowledge the provision of SS probe by Dr. Bimal Kumar Pramanik of the Department of Agricultural Extension, Bangladesh.

\section{REFERENCES}

BACLAYON, D.P., T. MATSUI, H. SUZUKI and Y. KOSUGI. 2006. Cloning, sequencing and sequence analysis of a cDNA encoding glutamate dehydrogenase gene in broccoli during postharvest senescence. Biotechnology 5(2): 118-124.

BUCHANAN-WOLLASTON, V., E. SIMON, H. ELEZABETH, M. EVY, N. SAEID, P. TANIA and P. DAVID. 2003. The molecular analysis of leaf senescence-a genomics approach. Plant Biotechnol. J. 1: 3-22.

CHENGAPPA, S., N. LOADER and R. SHILEDS. 1998. Cloning expression and mapping of second tomato sucrose gene, Sus 3. Plant Physiol. 118: 1533-1543.

CHOPRA, S., J. DELFAVERO, R. DOLFERUS and M. JACOBS. 1992. Sucrose synthase of Arabidopsis: Genomic cloning and sequence characterization. Plant Mol. Biol. 18: 131-134.

COUPE, S., B. SINClAIR, L. WATSON, J. HEYES and J. EASON. 2003. Identification of dehydration-responsive cysteine protease during postharvest senescence of broccoli florets. J. Experimental Bot. 54: 1045-1056. 
DAVIES, K.M., J.F. SEELYE, D.E. IRVING, W.M. BORST, P.L. HURST and G.A. KING. 1996. Sugar regulation of harvest related genes in asparagus. Plant Physiol. 111: $877-883$.

FU, H. and W.D. PARK. 1995. Sink and vascular sucrose synthase functions encoded by different gene classes in potato. The Plant Cell 7: 1369-1385.

HUANG, J.W., J.T. CHEN, W.P. YU, L.F. SHYUR, A.Y. WANG, H.Y. SUNG, P.D. LEE and J.C. SU. 1996. Complete structure of three rice sucrose synthase isogenes and differential regulation of their expressions. Biosci. Biotechnol. Biochem. 60: 233-239.

HUBBARD, N.L., S.C. HUBER and D.M. PHARR, 1989. Sucrose phosphate synthase and acid invertase as determinants of sucrose concentration in developing muskmelon (Cucumis melo L.) fruits. Plant Physiol. 91: 1527-1534.

ICHIMURA, K., K. KOJIMA and R. GOTO. 1999. Effect of temperature, 8hydroxyquinoline sulphate and sucrose on the vase life of cut rose flowers. Postharvest Biol. Technol. 15: 33-40.

IRVING, D.E. and D.C. JOYCE. 1995. Sucrose supply can increase longevity of broccoli (Brassica oleracea) branchlets kept at $22^{\circ} \mathrm{C}$. Plant Growth Regul. 17: 251256.

IRVING, D.E. and P.L. HURST. 1993. Respiration, soluble carbohydrates and enzymes of carbohydrate metabolism in tips of harvested asparagus spears. Plant Sci. 94: 89-97

KASSINEE, S., T. MATSUI and N. OKUDA. 2004. Changes in acid invertase activity and sugar distribution during postharvest senescence in vegetable soybean. Asian J. Plant Sci. 3(4): 433-438.

KING, G.A. and S.C. MORRIS. 1994. Physiological changes of broccoli during early postharvest senescence and through the preharvest-postharvest continuum. $J$. Amer. Soc. Sci. 119(2): 270-275.

KOCH, K.E. 1996. Carbohydrate-modulated gene expression in plants. Ann. Rev. Plant Physiol. Plant Mol. 47: 509-540.

KOCH, K.E., K.D. NOLTE, E.R. DUKE, D.R. MCCARTY and W.T. AVIGNE. 1992. Sugar levels modulate differential expression of maize sucrose synthase genes. The Plant Cell 4: 59-69.

LOWRY, O.H., ROSEBROUGH, N.J., FARR, A.L. and R. RENDALL. 1951. Protein measurement with folin-phenol reagent. J. Biol. Chem. 193: 265-275.

MARTIN, T., W.B. FROMMER, M. SALANOUBAT and L. WILLMITZER. 1993. Expression of an Arabidopsis sucrose synthase gene indicates a role in metabolizing of sucrose both during phloem loading and in sinks organs. Plant 4: 367-377. 
MARTINEZ DE ILARDUYA, O., J. VICENTE-CARBAJOSA, P. SANCHEZ DE LA HOZ and P. CARBONERO. 1993. Sucrose synthase gene in barley: cDNA cloning of the SS2 type and tissue specific expression of SS1 and SS2. FEBS Lett. 320: 177-181.

MCKENZIE, M.J., L.A. GREER, J.A. HEYES and P.L. HURST. 2004. Sugar metabolism and compartmentation in asparagus and broccoli during controlled atmosphere storage. Postharvest Biol. Technol. 32: 45-56.

NISHIKAWA, F., T. IWAMA, M. KATO, H. HYODO, Y. IKOMA and M. YANO. 2005. Effect of sugar on ethylene biosynthesis and responsiveness in harvested broccoli florets. Postharvest Biol. Technol. 36: 157-165.

PRAMANIK, B.K., T. MATSUI, H. SUZUKI and Y. KOSUGI. 2005. A sucrose synthase gene from broccoli: cDNA cloning, sequencing and its expression during storage. Biotechnology 4(4): 288-295.

ROSA, E., M. DAVID and M.H. GOMES. 2001. Glucose, fructose and sucrose content in broccoli, white cabbage and Portuguese cabbage grown in early and late seasons. J. Sci. Food Agric. 81: 1145-1149.

RUAN, Y.L., P.S. CHOUREY, D.P. DELMER and L. PEREZ-GRAU. 1997. The differential expression of sucrose synthase in relation to diverse patterns of carbon partitioning in developing cotton seed. Plant Physiol. 115: 375-385.

SITTHIWONG, K., T. MATSUI, N. OKUDA and Y. KOSUGI. 2007. Cloning and sequencing of sucrose synthase cDNA from vegetable soybean and its expression during storage at $20^{\circ} \mathrm{C}$. Biotechnology 6(2): 184-192.

SMEEKENS, S. 2000. Sugar-induced signal transduction in plants. Ann. Rev. Plant Physiol. Plant Molec. Biol. 51: 49-81.

SMIRNOFF, N. and J.E. PALLANCA. 1996. Ascorbate metabolism in relation to oxidative stress. Biochem. Soc. Transactions 24: 472-278.

SUTHUMCHAI, W., T. MATSUI, K. KAWADA and Y. KOSUGI. 2007.Sugar metabolizing enzymes activities in lettuce head during low temperature storage. Asian J. Plant Sci. 6: 568-576.

STITT, M. and U. SONNEWALD. 1995. Regulation of metabolism in transgenic plants. Ann. Rev. Plant Physiol. Plant Mol. Biol. 46: 341-368.

VERLINDEN, S. and J.J.V. GARCIA. 2004. Sucrose loading decreases ethylene responsiveness in carnation (Dianthus caryophyllus cv. White Sim) petals. Postharvest Biol. Technol. 31: 305-312.

WANG, M.B., D. BOULTER and J.A. GATEHOUSE. 1992. A complete sequence of rice sucrose synthase (RSS1) gene. Plant Mol. Biol. 19: 881-885. 